Copyright (C) 2021 University of Bucharest Printed in Romania. All rights reserved

ISSN print: 1224-5984

ISSN online: 2248-3942
Rom Biotechnol Lett. 2021; 26(3): 2692-2699 doi: $10.25083 / \mathrm{rbl} / 26.3 / 2692.2699$

Received for publication, November, 25, 2019

Accepted, August, 14, 2020

\author{
Original paper
}

\title{
The effect of fish bone bioactive peptides on the wound healing process; an in vitro study on keratinocytes
}

\author{
ANDREEA IOSAGEANU ${ }^{1}$, ANCA OANCEA ${ }^{1}$, DANIELA ILIE ${ }^{1}$, ELENA DANIELA \\ ANTON $^{1}$, OANA CRACIUNESCU ${ }^{1}$
}

${ }^{1}$ Department of Cellular and Molecular Biology, National Institute of R\&D for Biological Sciences, 296 Splaiul Independentei, 060031 Bucharest, Romania

\begin{abstract}
Fish bones mainly contain type I collagen and hydroxyapatite, and despite of their potential for applications in biotechnology and biomedicine, they represent one of the major source of waste generated by fish processing industry. The present study was focused on the interaction of bioactive peptides extracted from silver carp ( $\mathrm{H}$. molitrix) bones with human keratinocytes in culture. The potential of fish bone bioactive peptides to influence cell viability, proliferation and migration was evaluated in different experimental models in vitro. The results demonstrated a high efficiency and bioactivity of the enzymatically extracted fish bone peptides in several processes involved in cutaneous wound healing, in particular stimulation of keratinocytes metabolism and migration. In conclusion, they present a huge potential for applications in skin tissue engineering, but also in the biomedical and cosmetic fields.
\end{abstract}

Keywords Collagen, silver carp, cell viability, scratch assay, actin.

To cite this article: IOSAGEANU A, OANCEA A, ILIE D, ANTON ED, CRACIUNESCU O. The effect of fish bone bioactive peptides on the wound healing process: an in vitro study on keratinocytes. Rom Biotechnol Lett. 2021; 26(3): 2692-2699. DOI: $10.25083 / \mathrm{rbl} / 26.3 / 2692-2699$

*Corresponding author: ANDREEA IOSAGEANU, National Institute of R\&D for Biological Sciences, 296 Splaiul Independentei, 060031, Bucharest, Romania, Tel:+40-21-2200882

E-mail: andreea.iosageanu@gmail.com 


\section{Introduction}

Collagens are the major group of structural proteins found in the extracellular matrix of all eukaryotic tissues (COOPER, 2007). The main source of collagen for biomedical and cosmetic use is based on bovine and porcine tissues, such as skin, tendon, cartilage, etc. Due to medical concerns and religious believes aquatic species, such as fishes and invertebrates were lately considered an alternative source of collagen for a variety of applications in several domains (MATSUMOTO, 2006). Over the last decade, aquatic species served to recover many bioactive compounds for regenerative medicine, collagen being the most common used biomaterial in tissue management due to its biocompatibility (BINSI, 2013).

Hypophthalmichthys molitrix, also known as silver carp, is one of the most popularly cultured species of freshwater cyprinid fish used in food industry. The bones and scales represent an important part of silver carp processing waste, with a high content in type I collagen and hydroxyapatite $\left(\mathrm{Ca}_{10}(\mathrm{OH})_{2}\left(\mathrm{PO}_{4}\right)_{6}\right)$, which recommend them as a rich source of bioactive compounds with biomedical and cosmetic potential (SUO-LIAN, 2017; SENEVIRATHNE, 2012). For the recovery of these bioactive compounds from fish by-products, enzymatic hydrolysis is the recommended method for research and industry, based on the use of numerous acid or neutral proteases, such as: alkalase, papain, pepsin, trypsin, $\alpha$-chymotrypsin, pancreatin, flavourzyme, pronase, neutrase, protamex, bromelain, cryotin $\mathrm{F}$, protease $\mathrm{N}$, protease $\mathrm{A}$, orientase, thermolysin, validase, etc. (VILLAMIL, 2016). Enzymatic hydrolysis offers the advantages of mild reaction conditions and specificity of enzymes, controls the degree of hydrolysis and can provide the final bioactive products needed for biomedical applications (PASUPULETI, 2010).

The healing process involves proliferation and migration of cells and synthesis of new extracellular matrix (GUO, 2010). Several reports showed that cell proliferation and migration were promoted by peptides extracted from different species of marine fish. In vivo tests using fish type I collagen hydrolyzate (Amino collagen, Meiji Seika, Tokyo, Japan) taken orally showed an increase in the moisture content of the face cheek, the improvement of the viscoelasticity and a lower sebum content (MATSUMOTO, 2006). Peptides extracted from tuna back-bone, sardine muscle (SENEVIRATHNE, 2012) and bulk fish protein hydrolysates from defatted salmon backbones presented antioxidant properties (SLIZYTE, 2016), and also protein hydrolysates from cod muscle were found to contain growth factors or secretagogues (RAVALLEC, 2000).

In this study, we have evaluated the interaction of silver carp bioactive peptides with human keratinocytes, in particular their effect on cells metabolism and migration, using experimental models in vitro related to the wound healing process. Quantitative data regarding the rate of cell viability and migration and qualitative observations on cell morphology changes were provided.

\section{Materials and Methods}

\section{Preparation of bioactive peptides}

Bioactive peptides were obtained from skeleton bones recovered after fish processing, using a lab technology based on enzymatic hydrolysis (Figure 1).

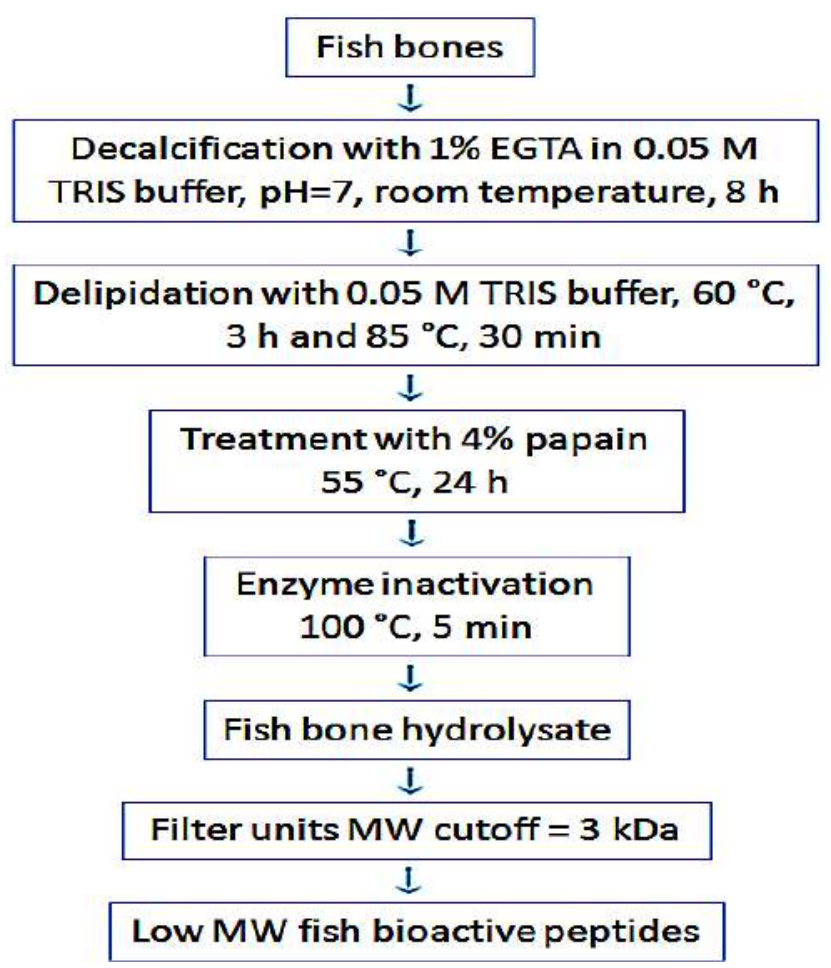

Figure 1. Lab technology for enzymatic preparation of silver carp bone hydrolysate and a fraction of low MW bioactive peptides. 
Briefly, fish bones were thoroughly washed in tap water and blended with distilled water in a weight ratio of $1: 1$, until a homogenate was obtained. Decalcification of bone tissue was performed by incubation in 1\% EGTA solution in $0.05 \mathrm{M}$ Tris buffer, $\mathrm{pH} 7$, under mild stirring, at room temperature, for $8 \mathrm{~h}$. Then, delipidation took place by thermal treatment of the minced tissue in $0.05 \mathrm{M}$ Tris buffer, $\mathrm{pH} 7$, at $60^{\circ} \mathrm{C}$, for $3 \mathrm{~h}$ and at $85^{\circ} \mathrm{C}$, for $30 \mathrm{~min}$. After cooling at room temperature, the minced tissue was subjected to enzymatic digestion by incubation in $4 \%$ (w/v) papain solution, with gentle stirring, at $55^{\circ} \mathrm{C}$, for $24 \mathrm{~h}$. Then, the solution was incubated at $100^{\circ} \mathrm{C}$, for $5 \mathrm{~min}$ to stop the enzymatic reaction and centrifuged at $8000 \mathrm{~g}$, for $20 \mathrm{~min}$. The supernatant, representing the fish bone hydrolysate, was subjected to centrifugal ultrafiltration through membranes with $3 \mathrm{kDa}$ molecular weight (MW) cutoff (Amicon) at $7500 \mathrm{~g}$, for $25 \mathrm{~min}$. Both fish bone hydrolysate and the fraction of low MW bioactive peptides were stored at $-20^{\circ} \mathrm{C}$, until further analyses. The dry weight was measured at a thermobalance, to calculate the extraction yield and the protein content was determined using BCA assay.

\section{Fish bone hydrolysate electrophoresis}

Silver carp bone hydrolysate was analyzed using the Tricine-SDS-polyacrylamide electrophoresis protocol, as previously described for proteins smaller than $30 \mathrm{kDa}$ (SCHAGGER, 2006). Briefly, the gel system was achieved by polymerization of a $16 \%$ acrylamide separating gel and a $4 \%$ acrylamide concentration gel in a vertical gel electrophoresis unit (Biometra). The sample was mixed with nonreducing sample buffer in a ratio of $2: 1(\mathrm{v} / \mathrm{v})$, heated at $40^{\circ} \mathrm{C}$, for $30 \mathrm{~min}$ and loaded onto the concentration gel. Migration was carried out at $60 \mathrm{~V}$ for $2.5 \mathrm{~h}$. After Coomassie staining, the bands were visualized and photographed. Bacitracin (1423 Da, Sigma) and insulin (5777 Da, Sigma) were migrated in the same conditions to serve as molecular weight markers.

\section{Cell culture and treatment}

HaCaT human keratinocytes were cultured in RPMI 1640 culture medium, supplemented with $10 \%$ fetal bovine serum (FBS) and $1 \%$ antibiotics mixture of penicillin, streptomycin and neomycin (PSN), in humid atmosphere with $5 \% \mathrm{CO}_{2}$, at $37^{\circ} \mathrm{C}$. For experiments, subconfluent cells were trypsinized, seeded in $35 \mathrm{~mm}$ Petri dishes, at a density of $6 \times 10^{4}$ cells $/ \mathrm{ml}$ and incubated overnight for adhesion. On the next day, the cells were cultured in fresh medium, with or without FBS, containing fish bone bioactive peptides of low $\mathrm{MW}$, in the range of concentrations $0.03-1.5 \mathrm{mg} / \mathrm{ml}$. The dishes were incubated in standard conditions for another $48 \mathrm{~h}$.

\section{Cell viability assessment by MTT test}

The effect of bioactive peptides on cell viability was determined by MTT colorimetric assay, an indicator of cellular metabolic activity at mitochondrial dehydrogenases level, as previously described (CRACIUNESCU, 2014). Briefly, at the end of incubation, the culture medium was replaced with fresh medium containing $0.25 \mathrm{mg} / \mathrm{ml}$ 3-(4,5-dimethylthiazol-2-yl)-2,5-diphenyltetrazolium bromide (MTT), in each well and the plates were incubated at $37^{\circ} \mathrm{C}$, for $3 \mathrm{~h}$. The resulted formazan crystals were solubilized with isopropanol and then, the absorbance of the coloured solution was measured at $570 \mathrm{~nm}$. Cell viability was calculated by reporting the sample value to the untreated culture (control) value, considered as $100 \%$ viable. The absorbance values are direct proportional to the number of viable cells, being an indicator of the degree of cell proliferation (MOSMANN, 1983).

\section{Cell morphology observations by light microscopy}

Cells cultivated in the presence of fish bioactive peptides, in the same conditions as described above, were periodically examined to observe changes at the morphological level. Light micrographs of the treated cells were acquired at $48 \mathrm{~h}$ using an AxioStar Plus phase contrast microscope (Carl Zeiss) equipped with a digital camera and software. Untreated cells were observed as control culture.

\section{Wound Healing Assay}

The effect of fish bone bioactive peptides on cell migration was measured using in vitro wound healing or scratch assay (LIANG, 2007). The mechanical scratch was performed at confluence of human keratinocytes using a pipette tip. Then, cells were cultured in the presence of fish bone peptides added in the culture medium supplemented with FBS. The concentration of bioactive peptides was chosen following the viability tests and cells without treatment were used as control. The scratch was photographed initially and after $6 \mathrm{~h}$ of cultivation at an AxioStar Plus phase contrast microscope (Carl Zeiss). The images were analyzed using ImageJ software to evaluate cell migration.

\section{Tubulin and actin visualization by fluorescent microscopy}

Cytoskeleton changes were observed after cell staining with anti- $\beta$-tubulin antibody and phalloidin-TRITC for f-actin by fluorescence microscopy, as previously described, with slight modifications (KRZYSIEKMACZKA, 2010). HaCaT cells were seeded on glass coverslips and after $24 \mathrm{~h}$ of cultivation, fish peptides were added in the culture medium supplemented with FBS and incubation continued for another $48 \mathrm{~h}$. Then, cells were processed for cytochemistry observations by fixation in $4 \%$ paraformaldehyde, permeabilization with $0.1 \%$ Triton X-100 and blocking with 1\% BSA in PBS supplemented with $0.05 \%$ Tween 20 (PBST). For microtubule staining, cells were incubated with rabbit anti- $\beta$-tubulin 
primary antibody, at $4^{\circ} \mathrm{C}$, overnight and then with goat anti-rabbit IgG secondary antibody conjugated with Alexa Fluor 488 fluorochrome, at room temperature, for $45 \mathrm{~min}$. Then, cells were incubated with phalloidin-TRITC for f-actin staining, at room temperature, for $50 \mathrm{~min}$. Finally, cells were washed and visualized at an AxioStar Plus microscope (Carl Zeiss).

\section{Statistical Analysis}

Statistical analysis was performed for cell viability results expressed as mean value \pm standard deviation (SD) of three independent samples $(n=3)$ using two-tailed, two-sample equal variance Student's $t$-test. Differences were considered statistically significant at $p \leq 0.05$, as minimal level of significance.

\section{Results}

\section{Characterization of bioactive peptides from fish bone hydrolysate}

An opalescent solution of fish bone bioactive peptides with low odour was obtained by papain treatment of silver carp minced bones. The extraction yield was calculated at $8.4 \%$. The electrophoresis pattern of fish bone hydrolysate is presented in figure 2 . The sample migrated as a single band between the markers of bacitracin and insulin. From this pattern, a molecular weight of $3600 \mathrm{Da}$ was calculated for bioactive peptides from fish bone hydrolysate, visualized by electrophoresis in TricineSDS-polyacrylamide gel.

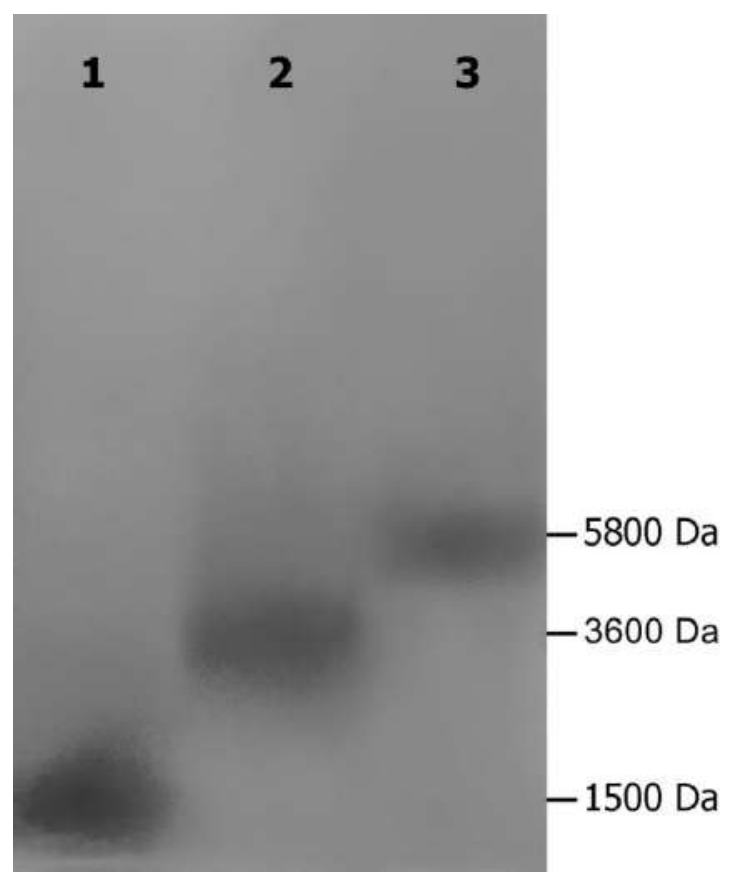

Figure 2. Tricine-SDS-polyacrylamide gel electrophoresis of bioactive peptides from silver carp bone hydrolysate (lane 2). Markers of bacitracin (lane 1) and insulin (lane 3) were migrated in the same conditions.

\section{Peptides effect on cell viability}

Results of cell viability determination are presented in Figure 3. The data showed that the percentage of cell viability for HaCaT keratinocytes cultivated in the presence of silver carp bone peptides, with or without FBS was higher than $70 \%$. This indicated that they were cytocompatible in a wide range of concentrations $(0.03-1.5 \mathrm{mg} / \mathrm{ml})$. At a concentration of $0.12 \mathrm{mg} / \mathrm{ml}$, fish bioactive peptides stimulated cell metabolism and the values of cell viability were the highest in both the presence $(111 \%)$ or in the absence $(114 \%)$ of FBS. The values were significantly higher $(p<0.05)$ than that of untreated cells $(100 \%)$, in both experimental conditions, but the difference between them was not statistically significant $(p>0.05)$. At higher concentrations of bioactive peptides, the cells cultured in medium with FBS presented viability values that decreased in a concentration-dependent manner down to $73 \%$, but remained in the low to moderate cytotoxicity domain (70-80\%). The same concentrations of fish bone peptides added in medium without FBS induced little variation between cell viability values and they were slightly higher than that of untreated cells (control, 100\%). 


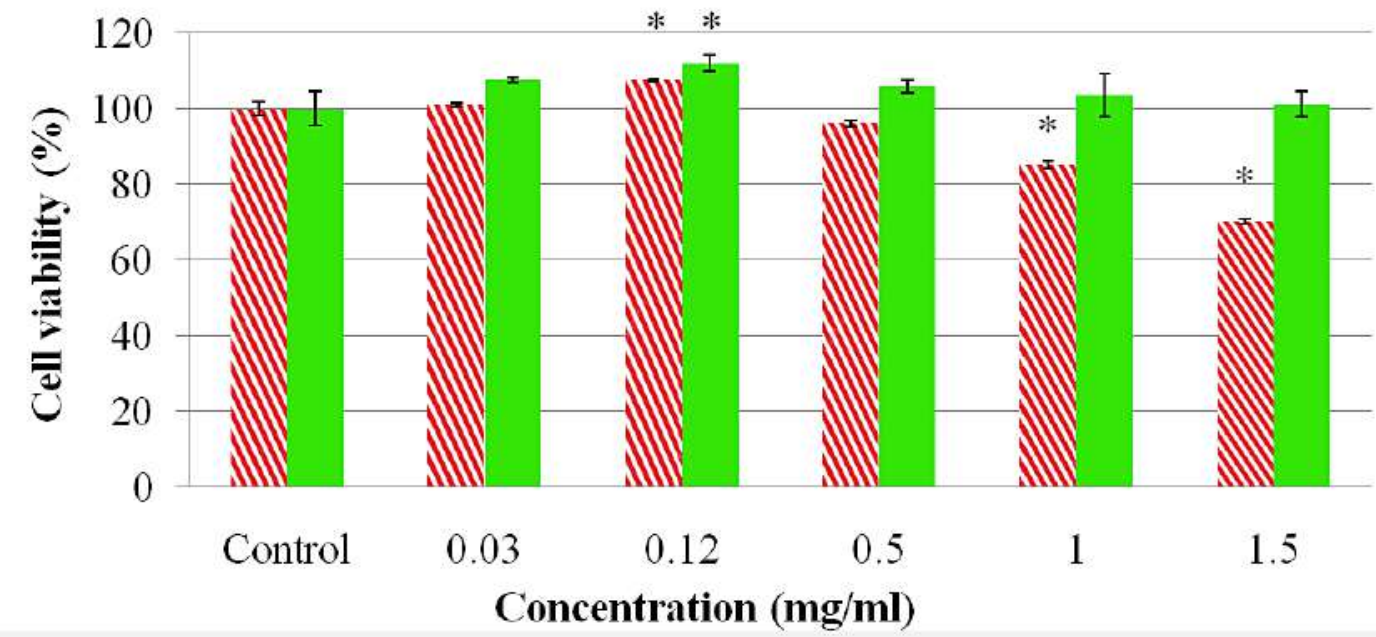

\section{HaCaT with Fetal Bovine Serum $\quad \mathrm{HaCaT}$ without Fetal Bovine Serum}

Figure 3. Cell viability of HaCaT keratinocytes cultivated in the presence of silver carp bone bioactive peptides, with and without FBS, for $48 \mathrm{~h}$, determined by MTT assay; ${ }^{*} p<0.05$, compared to control cells.

Light microscopy observations confirmed the cytocompatibility of bioactive peptides in HaCaT culture. The images showed that cells treated with bioactive peptides exhibited no alterations at morphological level (Figure 4).
HaCaT keratinocytes presented the specific polygonalshaped morphology with clear cytoplasm, arranged in a typical monolayer pattern. The cell density was similar to that of the untreated cells (control).
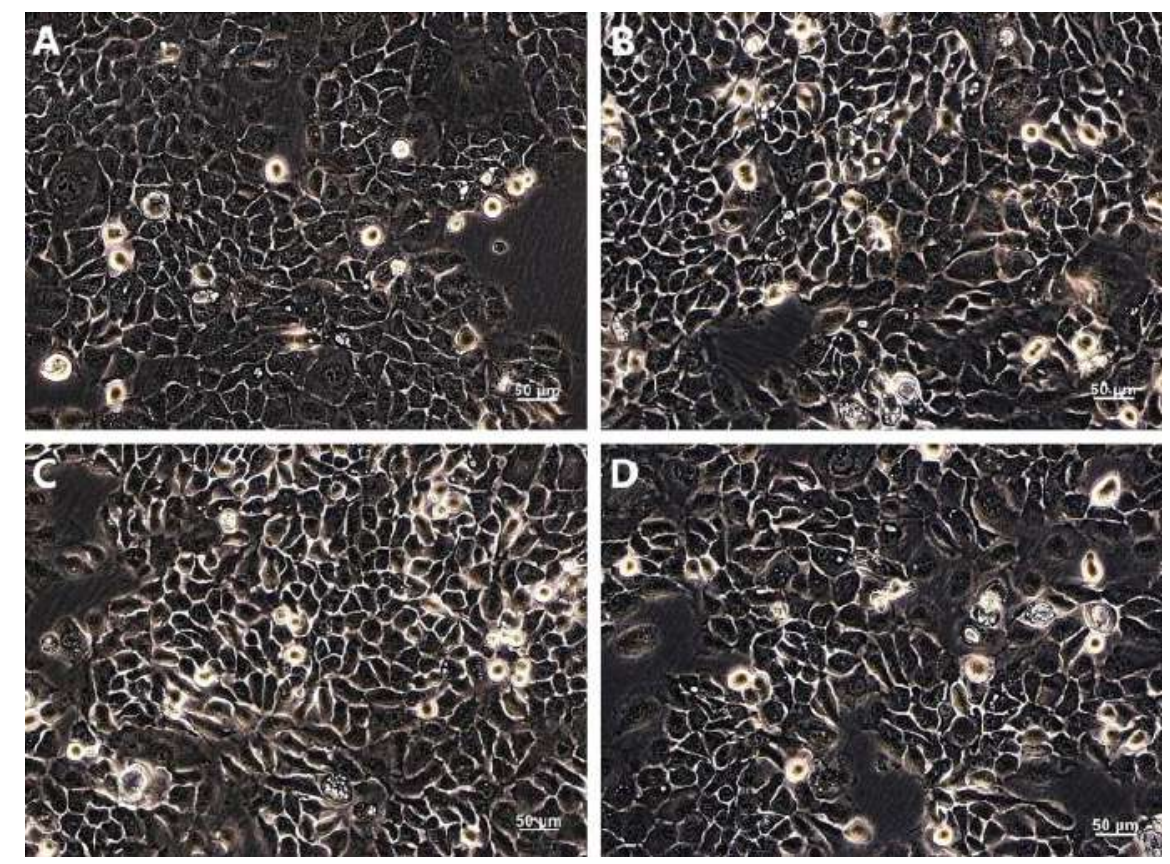

Figure 4. Phase-contrast microscopy images of HaCaT cells after $48 \mathrm{~h}$ of treatment with $0.12 \mathrm{mg} / \mathrm{ml}$ fish bioactive peptides. Cells without treatment were used as control. A - control; $\mathbf{B}-0.03 \mathrm{mg} / \mathrm{ml}$; C $-0.12 \mathrm{mg} / \mathrm{ml} ; \mathbf{D}-0.5 \mathrm{mg} / \mathrm{ml}$ (x20 magnification). 


\section{Peptides effect on cell migration}

The results of wound healing assay are presented in Figures 5 and 6 . In the presence of fish bone bioactive peptides, HaCaT keratinocytes exhibited a significant increase of cell migration after $6 \mathrm{~h}$ of cultivation (Figure $5 \mathrm{D}$ ).
The untreated cells indicated the native rate of cell migration (Figure $5 \mathrm{C}$ ). Image analysis showed that the rate of wound healing in treated cells $(60.6 \%)$ was significantly higher $(p<0.05)$, as compared with the control group (47.5\%), (Figure 6).
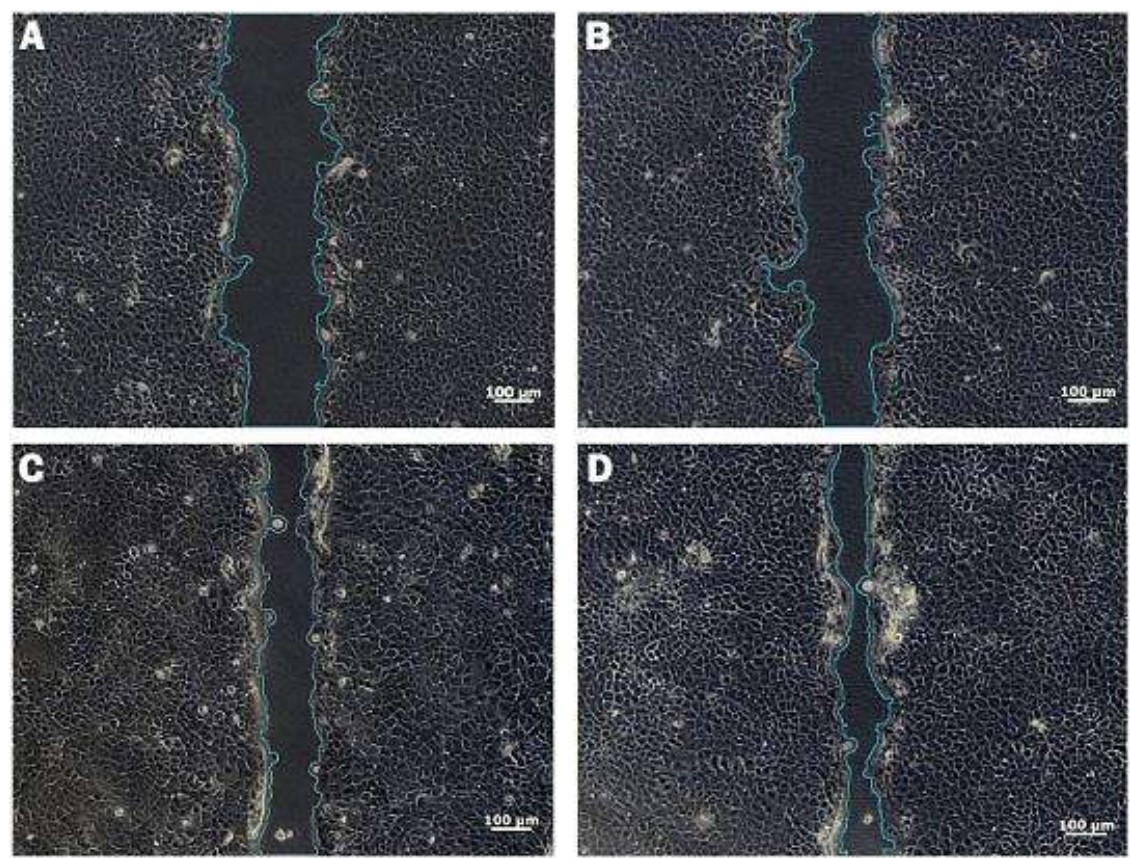

Figure 5. Phase-contrast microscopy images of $\mathrm{HaCaT}$ cells scratched and treated with $0.12 \mathrm{mg} / \mathrm{ml}$ fish bioactive peptides. Cells without treatment were used as control. $\mathbf{A}-$ control at $t=0 ; \mathbf{B}-$ treated cells at $t=0$; $\mathbf{C}$ - control after $6 \mathrm{~h}$ of cultivation; $\mathbf{D}$ - treated cells after $6 \mathrm{~h}$ of cultivation; (x10 magnification).

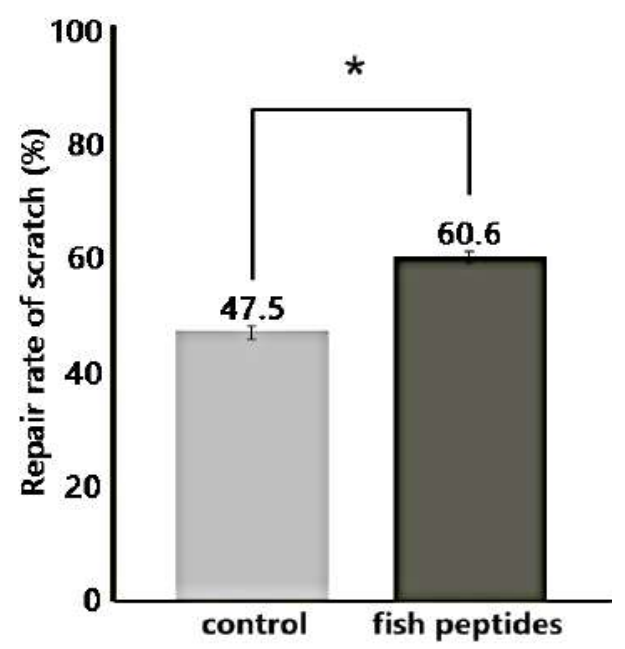

Figure 6. Repair rate of scratch determined by image analysis using ImageJ software; ${ }^{*} p<0.05$, compared to control cells.

\section{Observation of cytoskeleton components}

Two of the three major types of cytoskeletal proteins, $\beta$-tubulin and actin were investigated in the peptidetreated keratinocytes culture by cytochemical observations.
As shown in Figure 7A-F, no alterations in the cytoskeletal structures were observed after $\mathrm{HaCaT}$ cells treatment with fish bone bioactive peptides for $48 \mathrm{~h}$. Filopodia and intercellular filaments were present (Figure 7F). 

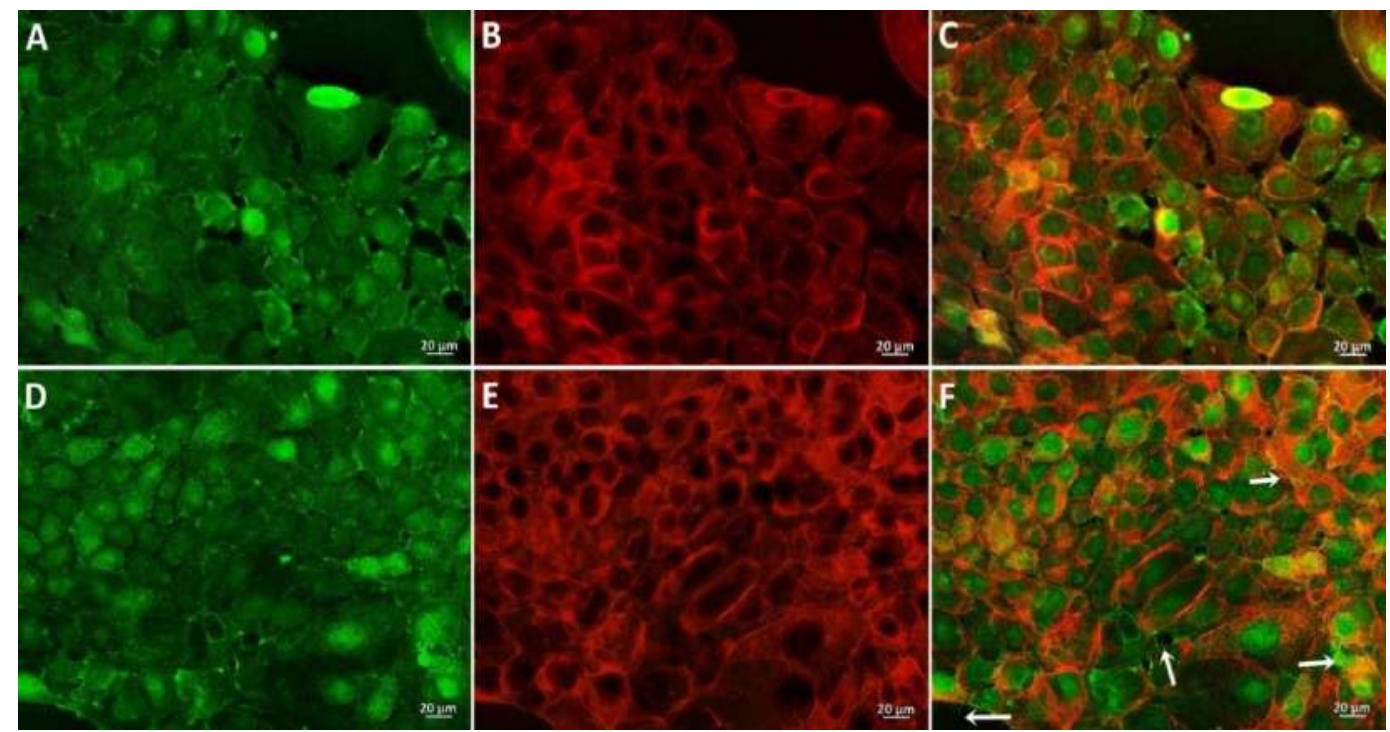

Figure 7. Cytochemistry images of $\beta$-tubulin and f-actin in HaCaT cells treated with $0.12 \mathrm{mg} / \mathrm{ml}$ fish peptides for $48 \mathrm{~h}$, showing filopodia and intercellular filaments (white arrows). Cells without treatment were used as control. $\mathbf{A}$ - $\beta$-tubulin, control; $\mathbf{B}$ - f-actin, control; $\mathbf{C}$ - merged, control; $\mathbf{D}$ - $\beta$-tubulin, treated cells; $\mathbf{E}$ - f-actin, treated cells; $\mathbf{F}$ - merged, treated cells.

\section{Discussion}

Keratinocytes are the predominant cell type of the epithelial barrier and support the wound healing process together with fibroblasts, which secrete growth factors (WANG, 2012). This complex process is greatly influenced by cell proliferation and migration. Therefore, in our study, the biological properties of silver carp bone peptides were investigated on in vitro experimental models of human keratinocytes in culture, in the presence or absence of FBS. The viability tests showed that fish bone peptides were cytocompatible in a wide range of concentrations and stimulated keratinocyte cells metabolism and migration. As other studies have shown, proteins from FBS may interact with test compounds (KRAMER, 2012) and this could be a reason for which cells treated with bioactive peptides and cultivated in medium supplemented with FBS presented a lower viability, especially at increased sample concentrations. Also, cytometric analysis of cells showed that serum starvation could induce arrest in G1 phase in HaCaT cells (KIM, 2018), while the presence of gelatins extracted from tilapia fish scale promoted the progress through the cell cycle from G1 to $M$ phase (HUANG, 2018). In our study, the significant difference between the serum-starved control and treated cells could be similarly explained, namely cells succeeded to undergo mitosis due to the presence of fish bone bioactive peptides.

The bioactive peptides also demonstrated high capacity to influence the human keratinocytes migration process. In a wound-mimicking environment, the presence of silver carp bone peptides induced an increase of the wound closure process, after $6 \mathrm{~h}$ of cultivation. This effect was probably due to the presence of Gly-Pro-X and Gly-X-Hyp sequences, frequently encountered in the collagen molecule, and, as a result, in the peptides primary structure. These specific sequences were also reported as being involved in the chemotactic attraction of human fibroblasts (POSTLETHWAITE, 1978).

The cytoskeleton includes three major types of proteins: actin, tubulin and intermediate filaments (DANG, 2017). In our study, examination of cytoskeletal structures, such as actin and tubulin showed that silver carp bone peptides were biocompatible with $\mathrm{HaCaT}$ human keratinocytes and induced neither cellular stress nor cytoskeletal changes. The presence of filopodia and intercellular filaments is known to be associated with cellular adhesion and migration ( $\mathrm{Yu}, 2018)$. Previous studies have pointed that collagen contained the arginineglycine-aspartic acid (RGD) motif, specific for cell adhesion (YAMADA, 2014). A detailed research on RGD motif might contribute to understand how cell receptors bind to the motif and how collagen and collagen peptides could improve cell adhesion and migration.

\section{Acknowledgments}

This work was supported by CCCDI - UEFISCDI, project no. PN-III-P1-1.2-PCCDI-2017-0569 (PRO-SPER).

\section{Conflict of Interest}

The authors have no conflict of interest to declare. 


\section{Conclusions}

In conclusion, this study proposed an enzymatic method to prepare fish hydrolysate from $H$. molitrix bones and separation of low MW bioactive peptides by centrifugal filtration. It was demonstrated a high potential and efficiency of fish bones peptides to stimulate human keratinocytes metabolism and the process of cell migration involved in wound healing. At the same time, the lab technology of fish waste recovery can contribute to the bioeconomy growth by providing bioactive compounds, which represent a promising tool for cutaneous wound care management.

\section{References}

1. BINSI PK. Fish scale: a versatile biomaterial. INFOFISH, 2013; 3: 41-43.

2. COOPER GM, HAUSMAN RE. Cell Walls and the Extracellular Matrix. In The cell: a molecular approach. Washington D.C. ASM Press: 1752 N Street NW, Washington DC, USA, $4^{\text {th }}$ ed. 2007.

3. CRACIUNESCU O, GASPAR A, TRIF M, MOISEI M, OANCEA A, MOLDOVAN L, ZARNESCU O. Preparation and characterization of a collagenliposome-chondroitin sulfate matrix with potential application for inflammatory disorders treatment. J. Nanomater, 2014; 2014: 903691.

4. DANG DD, GERLACH BD. The roles and regulation of the actin cytoskeleton, intermediate filaments and microtubules in smooth muscle cell migration. Respir Res., 2017; 18-54.

5. GUO S, DIPIETRO LA. Factors affecting wound healing. J Dental Res., 2010; 89: 219-229.

6. HUANG CY, WU TC, HONG YH, HSIEH SL, GUO HR, HUANG RH. Enhancement of cell adhesion, cell growth, wound healing, and oxidative protection by gelatins extracted from extrusion-pretreated tilapia (Oreochromis sp.) fish scale. Molecules, 2018; 23: 2406-2422.

7. KIM HE, CHO H, ISHIHARA A, KIM B, KIM O. Cell proliferation and migration mechanism of caffeoylserotonin and serotonin via serotonin $2 \mathrm{~B}$ receptor in human keratinocyte HaCaT cells. BMB Rep., 2018; 51(4): 188-193.

8. KRAMER NI, KRISMARTINA M, RICO-RICO A, BLAAUBOER BJ, HERMENS JLM. Quantifying processes determining the free concentration of phenanthrene in basal cytotoxicity assays. Chem Res Toxicol., 2012; 25: 436-445.

9. KRZYSIEK-MACZKA G, MICHALIK M, MADEJA $\mathrm{Z}, \mathrm{KOROHODA} \mathrm{W}$. Involvement of cytoskeleton in orientation of cell division in contact guided cells. Folia Biol., 2010; 58: 21-7.

10. LIANG CC, PARK AY, GUAN JL. In vitro scratch assay: a convenient and inexpensive method for analysis of cell migration in vitro. Nat Protoc., 2007; 2(2): 329-333.

11. MATSUMOTO H, OHARA H, ITO K, NAKAMURA Y, TAKAHASHI S. Clinical effects of fish type I collagen hydrolysate on skin properties. ITE Lett Batter New Technol Med., 2006; 7: 386-390.

12. MOSMANN T. Rapid colorimetric assay for cellular growth and survival: application to proliferation and cytotoxicity assays. J. Immunol. Methods, 1983; 65: 55-63.

13. PASUPULETI VK, BRAUN S.PASUPULETI VK, DEMAIN AL. State of the art manufacturing of protein hydrolysates. In Protein hydrolysates in biotechnology. Springer Dordrecht Heidelberg: New York, NY, USA, 2010.

14. POSTLETHWAITE AE, SEYER JM, KANG AH. Chemotactic attraction of human fibroblasts to type I, II and III collagens and collagen-derived peptides. Proc Natl Acad Sci USA, 1978; 75: 871-875.

15. RAVALLEC PLE R, GILMARTIN L, WORMHOUDT AV, GAL Y. Influence of the hydrolysis process on the biological activities of protein hydrolysates from cod (Gadus morhua) muscle. J Sci Food Agr., 2000; 80: 2176-2180.

16. SCHÄGGER H. Tricine-SDS-PAGE. Nat Protoc., 2006; 1(1): 16-22.

17. SENEVIRATHNE M, KIM SK. Development of bioactive peptides from fish proteins and their health promoting ability. Adv Food Nutr Res., 2012; 65: 235-248.

18. SLIZYTE R, ROMMI K, MOZURAITYTE R, ECK P, FIVE K, RUSTAD T. Bioactivities of fish protein hydrolysates from defatted salmon backbone. Biotechnol Rep (Amst), 2016; 11: 99-109.

19. SUO-LIAN W, HUAI-BIN K, DONG-JIAO L. Technology for extracting effective components from fish scale. J Food Sci Eng, 2017; 7(7): 351-358.

20. VILLAMIL O, VAQUIRO H, SOLANILLA JF. Fish viscera protein hydrolysates: production, potential applications and functional and bioactive properties. Food Chem, 2016; 224: 160-171.

21. WANG Z, WANG Y, FARHANGFAR F, ZIMMER M, ZHANG Y. Enhanced keratinocyte proliferation and migration in co-culture with fibroblasts. PLoS ONE, 2012; 7(7): e40951.

22. YAMADA S, YAMAMOTO K, IKEDA T, YANAGIGUCHI K, HAYASHI Y. Potency of fish collagen as a scaffold for regenerative medicine. BioMed Research International, 2014; 1-8.

23. YU H, GAO M, MA Y, WANG L, SHEN Y, LIU X. Inhibition of cell migration by focal adhesion kinase: time-dependent difference in integrin-induced signaling between endothelial and hepatoblastoma cells. Int J Mol Med, 2018; 41: 2573-2588. 